\title{
Customary International Law and General Principles of Law and the Protection of the Environment
}

\author{
Thepparat Phimolsathien
}

\begin{abstract}
It has been seen that international agreement has lack of effectiveness to protect the environment. Environmental Protection could not be addressed if standard liability has not been changed. It is very important to understand how the current international liability is working because it will show that efficient liability regime can protect the environment and polluter state will be liable for the damages. The effectiveness of international liability regime must be able to at least provide equitable allocation of cost of remedies, reparation of damage once it has occurred. Moreover, a good liability regime should ensure the polluter not to cause further environmental harm. This article introduced international customary Law and general principle of law as tools to protect environment. The customary law would consider being a very important source for the tribunal decision since the custom law deprive from the formulation of non binding principles, repetition of specific rules in the international context, the accommodations of the conflict arising between states and those precedent cases. General principle of law is another source and practices or universal guidelines, all of which can also be used as a tool to solve the conflict.
\end{abstract}

Index Terms-Environmental law, environmental protection, international customary law, and general principle of law.

\section{INTRODUCTION}

Environmental problems are not a new issue in the today's world forum. It had not been considered as a world problem until this century when the damages can easily be seen. In the past few centuries, the world environmental condition has been worsening for instance, since the industrial revolution, the atmosphere concentration of Carbon Dioxide has increased as a result, the green house affect and increase of atmosphere carbon dioxide will increase the earth's temperature an average at least two degree centigrade in surface temperature during the next century. The implication of it will produce a certain effect on many things such as Antarctica's ice cap which will result to the rise in the level of the Antarctica continent, earth axes, and movements of the earth various plates [1].

In the past forty years, the importance of environmental protection has been arising of how to protect and to prevent the environment harm and damages. The best way to protect the environment at the international forum is to sign the agreement among state to protect the environment and prevent the harm. Even though there have been a lot of environmental agreement signed at the international forum,

Manuscript received April 17, 2014; revised June 20, 2014.

Thepparat Phimolsathien is with the Administration and Management College, King Mongkut Institute of Technology, Ladkrabang Campus (e-mail: thepparat@hotmail.com). however, the efficiency and effectiveness of those agreements has been questioned.

The state has the rights and responsibility to monitor and to prevent environmental damages within their jurisdiction and, under the principle of international law, the state has also an obligation not to cause damage of other states. However, practically, it is a politically unwise for state to write down a very concrete agreement that bound them even though it is designed to protect the environment. Reason could be seen from a political pressure group within the state, especially from the developed countries where the industry which produce a lot of wastes have a lot of political influence of the government decision, which have a tremendous effect of the outcome and put a lot of obstacles to the development of the agreement at the international level. As a result, the desire of the treaty would be theoretically impossible to meet the demand of the environmental protection needed.

Protecting the environment has long been regarded as a first world country issue. After the 1960, many developing countries have been reluctant to commit to what the first world demanded, however, it is not because the developing countries do not concern about the environmental degradation but their economic development usually contradicts with the environmental protection. To be more specific, in order to increase the economic growth, productivity of goods must also increase, therefore the tendency of harming the environment also increased at the cost of which the developing countries could be uncompetitive compete with the developed countries. Moreover, at the international forum, in order to protect the environment the developing countries also find it difficult to meet the standard of the developed country at a high cost of technology transfer. Therefore, looking from the above paragraphs, it is not surprised to learn that the environmental protection and conservation picture that perceived by developed and developing countries is different. This difference can also be seen from two comments first by the head of Brazilian delegation at the Stockholm Conference in 1972.

"It is economic growth that has allowed developed countries to make great advances in the eradication of mass poverty, ignorance, disease and so such to give a high priority to environmental consideration. Mankind has legitimate needs that are material, aesthetic and spiritual. A country that has not yet reached minimum satisfactory level in the supply of essentials is not in a position to divert considerable resources to environmental protection."

And Ugandan Delegation Leader's statement, which consider the difference perception of the developed and developing countries environmental problem: 
"Developed countries face environmental problems different in degree from those encountered in developed countries of the world. Our fundamental problem is how to raise the material standard of life of our people to level that are humanly decent. In other words, we are not confronted with an environment that has endangered into pollution as a result of development. On the contrary, we are faced with an environmental, many of whose inherent aspects are prohibitive to development and injurious to human comfort.

So it can also be seen that at the international level, political unsettled climate between developed and developing country could also be considered as one of the major problems in settle out the international agreement. The political unsettle can be seen from a suggestion offered by Werner Levi also that:

"The issue of environmental legal controls is so difficult to settle not merely because of the nature of the issue but because it has not yet been settled politically. It is an excellent illustration of the principle that effective law must be preceded by effective political agreement. Otherwise states will take refuge in those existing legal principles giving them the widest freedom of behaviour. In this case that principle is territorial jurisdiction based on sovereign independence. This issue of legal controls is also an illustration of the state practice of solving new problems by adjusting existing norms rather than by making radical innovations in the existing legal system."

However, it does not mean that the developed countries do not find it to be difficult among themselves to commit to protecting the environment because it is being understood that most of the waste and pollution are from the developed country. Any commitment from the first world leaders would be domestically political unwise from the reduction of consumption and production which might hurt the industry and labour market.

Sovereign issue has also long been considered as a major obstacle for the environmental protection. State had long been considered as national sovereignty rights to exploit its national resources within their jurisdiction boundary and share the resources on a first come first serve basis on a common boundary without worrying the implication of the overexploited of the national resource of another country; however, this perception has been changed. This credit should go to the Trail Smelter case which has been considered as one of the most notable arbitration of all time because the language that used in the case indicated the country has the right to exploit her resource but such exploitation should not affect other as well. As stated that "the Tribunal, therefore, finds that under the principle of international law as well as the law of the United States...no State has the rights to use or permit the use of its territory in such a manner as to cause injury by fumes in or to the territory of another or the properties or person therein when there is of serious consequences and the injury is established by clear and convincing evidence".

At the international level, when there is an environmental problem caused by one state and such activity has certain effect to the other state. If they cannot solve the problem by the mediation or conciliation, then there will be a tribunal for resolving the conflicts between states. So the question come what kind of law do the tribunal use to decide such disputes. At the international level, there are two kinds of international law: Customary International Law and the binding law such as treaties: both bilateral and multilateral, that states have signed and ratified them. When states have signed and ratified those binding law, it is an obligation of states to abide/ bound by those rules and when there is a conflict, this binding agreement will be useful resources to solve the conflict between the parties.

It should not be a big problem if those laws in the binding agreement are specific and cannot be misinterpreted or redefined so when there is a breach of agreement, some form of mechanism or ways out could be found in the agreement, unfortunately, diplomatic pressures always give an abstract in the agreement. This also include the absence of the paragraph of state responsibility and liability, that means most of the international agreement still lack of sentence indicating the assurance of those rules that design to protect the environment damages when it is not properly implemented.

This article does not believe that it would be too difficult to draft a binding agreement that can effectively protect the environment and give an effective mechanism for the state responsibility as can be seen from Bamako Convention on the Ban of the import into Africa and the Control of trans-boundary movement and management of Hazardous Wastes within the African which consider to be one of the most well written convention that protect the importation of Hazardous waste.

Therefore, it is necessary to rethink of how could we use other sources of international law (other than imperfect treaty) that widely accepted as a tool to ensure that it can be used effectively to build a case for the protection of environment.

When there is an environmental problem within the state, the state or the government has its own sovereignty right to take any action against wrongful people or corporation. However, when it comes to the international level or between states, the state looks at the agreement whether such activity is the breach of an international agreement.

In the past, the international agreement was based mostly for economic and trades purposes. Even though, the environmental problem had begun long time ago especially after the industrial revolution started but it had not been a major issue in the world forum. After 1900s' until today, there have been numbers of international agreements that has to do with the international environmental issues or contain important provision that to protect and to monitor the environmental danger. Further more, nowadays, the environmental issue has gone to the level of stop harming and reduces all the waste or toxins that dismiss to the air, water, and soil.

However, as mentioned, the political interfere always make those agreements to be imperfect. Presumably, if the treaty cannot be written in a way that can effectively protect the environment, as it should be, then the agreement itself could be considered as a paper that drafted to serve for political purposes in which could hardly see any state breaching the agreement. So next question would be if there were a wrongful act occurred, what source other than thetreaty could be used effectively to build a case for an 
international liability regime.

Traditionally, international law has conditioned the imposition of state responsibility on a show of negligence [2]; unfortunately, the negligence concept does not seen to be working effectively. Even though [2], there seems to be general acceptance of a distinciton betwen responsbility based on subjective criteria pertaining to a state's conduct, and responsiblity based on objective criteria, however, there is a diversity of definition of these categories. According to which the form of state responsibility is determined not on the basis of a subjective concept of fault, but on the basis of the nature of the primary obligation that has been breached. "Fault" responsibility is defined as responsibility for the breach of an obligation of due diligence which in turn is an obligation of conduct. On the other hand the concepts fo strict and absolute responsibility as defined by Pisillo-mazzeschi, are understood to mean responsibility resulting from the breach of an absolute prohibition of an activity, which constitutes an obligaiton of result [2].

Even though a limited number of treaties addressing environmental issues do provide for "Strict: or "absolute" responsibility, in this sense, neither concept can be considerd as generally recognized in customary and treaty law relating to environmental protection.

Nowadays, practically, international liability standard that imposes liability only if the transoundary harm sustained was the consequence of a violation of an international obligation [3]. At the international level, there has been a study since 1978 regarding the international liability from injurious consequences arising out of acts not prohibited by international law. Until recently, the difficulty in agreeing in the fundamental question regarding the application of standard of liability whether it is based on stick or fault and the purpose of the draft whether it is for prevention or compensation still go on as can be seen below that:

The American Journal of Internaitonal Law commission has established a working group to consult the approach to be taken to the liability topic: on the recommendation of the working group, the commission:

1) Declined to take any final decision on the precise scope of the topic.

2) Decided that it should bover both prevention and remedial measures on the prevention should be consider first, and

3) Decided to deal, at least at his stage with acitivities involving a substantial risk of causing trans-boundary harm and not with other activities that, in fact,cause harm. In otehr words the commission will focus first on preventive measures in respoect of activbities creating a substantial risk of harm and then on remedial measures after harm has occured.

As a result, the work of ILC on liability still find an absence of consensus as a matter of political unsettled. Under the present international liability, the effectiveness of redress/compensation could hardly be implemented. It would be better if the victim state could be compensated from the situation in which the harm incurs without a casualty bench of international law by using the some sort of law that widely accepted. Stick liability would grant redress automatically after the accident.
At the international level, international convention or treaty are not the only source that the court or international look into as indicated in Article 38(1) of the Statute of the International Court of Justice "The court, whose function is to decide in accordance with international law such disputes as are submitted to it, shall apply:

1) International conventions, whether general or particular, establishing rules expressly recognised by the contesting states.

2) International custom, as evidence of a general practice accepted as law;

3) The general principles of law recognised by civilised nations.

4) Subject to the provisions of Article 59, judicial decisions and the teachings of the most highly qualified publicists of the various nations, as subsidiary means for the determination of rules of law.

Before going further, it would be better to illustrate the understanding of customary law and principle of international law.

\section{WHAT IS CUSTOMARY INTERNATIONAL LAW}

Customary International Law is a record of case decision at the international level. It is an "evidence of a general practise, accepted as law" [4]. Customary international law is needed and important to understand because the court decision is generally accepted in the international community such the ruling in the Trail Smelter case. As indicated in the Trail Smelter arbitration that "no state has the right to use its territory in such as manner as to cause injury to the atmosphere by emissions when serious consequences are evolved and the injury to the atmosphere is demonstrated by clear and convincing evidence" or the Lake Lanoux stated that "a state has the duty to give notice when its actions may impair the environmental enjoyment of another state". These customary rules' foundation has been used in many international treaty and bilateral agreement, as a basic understanding that state should follow. But the weaknesses of Customary International Law can be named such as it is not a law or binding obligation on states, there is no regulatory system to enforce it or any measure to prevent or protect the environmental damage to occur. Nonetheless, the relationship between Customary International Law and the liability regime, it plays an important role for the state to behave and follow and the arbitrator to consider the case as a primary source.

\section{WHAT IS THE GENERAL PRINCIPLE OF INTERNATIONAL LAW [5]}

In any system of law, a situation may very well arise where the court in considering a case before it realises that there is no law covering exactly that point, neither parliamentary statue nor judicial precedent. In such instances the judge will proceed to infer a rule that consider to be relevant, by analogy from already existing rules or directly from the general principles that guide the legal system, whether they be referred to as originating from justice, equity or 
considerations of public policy. The situation to use general principle of international could be more likely to happen in the international law because of the relative underdevelopment of the system in relation to the needs with which it is faced. There are fewer decided cases in international law than in a municipal system and no method of legislating to provide rules to govern new situations. It is for such reason that the provision of "the general principles of law recognised by civilised nations" was inserted in to article 38 as a source of law, to close the gap that might be uncovered in international law; nonetheless, it finds similar problems to the customary law. However, if it is accpeted, some general principle of law will be very useful in order to build a case to protect the environment. The general principle of Law does contain various fields including in the Principle 21 , the precautionary principle, duty to prevent, duty to inform, duty to assess, duty to mitigate the pollution, the ideas of common heritage of mankind, sustainable development, shifting the burnder of proof from the victim to the polluter, intergenerational responsibility, sustainable development, and etc.

Nowadays, the international liability standard still imposes liability only if the trans-boundary harm sustained was the consequence of a violation of an international obligation. As a result of this standard of liability, it means that it would be difficult to find any state to breach the obligation and liable of such activity. So far, there have been only few cases that brought before the international tribunal such as Trail Smelter, Lac Lanoux, Gut Dam, and Nuclear Tests Case.

However, the liability problem should not be the only factor that causes the ineffectiveness of the today's international environmental law. The following shall be included [6]:

1) State responsibility is based on the bilateral relationship between sovereign states with certain rights and duties towards each other's. It fails to provide a useful enforcement mechanism for holistic obligation.

2) The state responsibility provides only for remedial but not preventive action i.e. Restoration of the environmental and compensation of the victim after the damage has already occurred.

3) According to the rule of international law, a case can be brought only by the discretion of the state, not by individual or any non-government organization, therefore, as mentioned, state will politically reluctant to bring a case to the international tribunal but rather than resolve it through diplomatic negotiation in order to avoid the infringement of Diplomacy.

4) Procedural obstacles, the complexity, lengths, and expenses of the procedure, diplomatic pressures, and the fear of creativity a precedent will often prevent the submission of a claim by the "Victim State".

Therefore, the absence of well-written treaty to specify any unlawful activities and unfinalized of standard of state responsibility and lack of case law from the absence of diplomatic claim have created a no where to go universal guideline for the court decision in order to prevent and to protect the environment. It would be inefficient if the international tribunal or international court only rely on the interpretation of the loosen treaty without looking for another sources in order to build a case for an international liability.

As mentioned that customary law and international principle of law are the other sources that the ICJ looks at before deciding the case however, practically it is not popular to do so. The following explanations if we constantly use the customary law and principle of international, then it could be used effectively to build a case for protection of the environment. The example will illustrate the nature of both binding and non-binding law, which can be found in the Customary and principle of international law, has emerged. Therefore, it could be raised the importance and the acceptance of customary and principal of international law in those agreements as these two could facilitate the shift of the standard of liability from fault to stick liability.

It is understood that it would be difficult to find the firm commitment or any specific responsibility or liability in the international agreement. However, the debate whether the liability should be at fault or stick is beyond the scope of this article; however, the characteristic of those two has been mentioned. Nevertheless, it is very importance to see the idea behind of it when the international agreement both binding and non-binding is drafted. It is understood that political arena in the international forum creates many obstacles for nations to commit themselves to a very rigid agreements. However, some general principle which can be drawn out from those treaties or international agreement could be a very important source for the international tribunal to look at when they decide the case. The ICJ has already said that the customary law and principle of international law are included as a source of law.

Nowadays, as mentioned, the international environment problem is not a national problem anymore. The effect of one country has resulted to the neighboring country or to the global scale. Therefore, the basic principle of today international law could be seen as a source to claim for the liability of the Polluter State. For instance the widely accepted principle "Stockholm Declaration: Principal 21", which states that "A state has the duty to ensure that activity within its jurisdiction does not cause damage to the environment of another State". Or a basic rule of Tran-frontier pollution in the 1972 Stockholm Declaration stated in the Principle 21 states that "states have the responsibility to ensure that activities within their jurisdiction or control do not cause damage to the environmental of other States or areas beyond the limits of national jurisdiction". Therefore, if we look at those two sentences, it would be understood that if any country does environmental harm to another state, it is the state responsibility for such reparation. However, the principal still provides a room for a country's right to exploit their resource and conduct their own national policy for their economic development state that "the sovereign right of States to exploit their own resources pursuant to their own environmental policies".

It is also worth to mention about the decision of Trail Smelter case because the case seems to have a very influential of today many renowned convention/ treaty. The decision of Trail Smelter case was considered to be a no harm principle to the other states. This no harm principle has been widely accepted to protect the global environmental problem and extend to the areas beyond the limits of national 
jurisdiction such as Antarctica. These case has made an implication of what can also be seen, for instance [7], Article 194(2) of the 1982 UNCLOS which makes the similar point when it calls for states to prevent pollution spreading beyond areas where they exercise their rights, or at the United Nations General Assembly that affirmed that in the exploitation, exploration, and development of their natural resources, "States must not produce significant harmful effects in zones situated outside their national jurisdiction".

The Trail Smelter case also point out the importance of the State to do more than reparation which means that the states should take any suitable preventive measures to protect any future harm and the environment. This importance of this sentence can now be found in many treaties or conventions for instance [8] the Ozone Convention, the MARPOL Convention, the London Dumping Convention, and those dealing with land based pollution. The rule is also now primarily one of prevention and control indicated most clearly by Article 194 of the 1982 UNCLOS:

1) States has taken, individually or jointly as appropriate, all measures consistent with this Convention that are necessary to prevent, reduce and control pollution of the marine environment from any source, using for this purpose the best practical means at their disposal and in accordance with their capabilities, and they shall endeavor to harmonize their policies in this connection.

2) States shall take all measures necessary to ensure that activities under their jurisdiction or control are so conducted as not to cause damange by pollution to toehr states and their environment.

There are the other two prinicples that worth to mention, the priciple to access and precautionary priniciple which also indicate some contribution to the environmental protection.

Principle to access: Nowadays, many of the projects from many leading international organization such as World Bank do need an environmental impact assessment prior the project starts. It indicates that the states need to conduct this test in order to ensure that such project would not have any impact to the other countries or area beyond their national jurisdiction. In the international treay such as Article 206 of the 1982 UNCLOS is a convention that formulates this obligation stated that "When states have reasonable grounds for believing that planned activities under their jurisdiction or control may cause substantial pollution of or significant and harmful changes to the marine environment, they shall, as far as practicable assess the potential effects of such activities on the marine environment and shall communicate reports of the results of such assessment to LMO”.

Precautinary Priniciple: It is the other principle that can be used effectively to protect the environment. Many states may have use scientific uncertainty as a way to escape from any obligation and many times with this excuse; it causes a delay of a negotiation. So in order to ensure that the environmental is protected, the precautionary principle can be used as a need to prevent any unforeseeable harm that might happen.

\section{CASE LaW (Customary LaW)}

Case law is important to understand for instance Corfu
Channel case. It is a very good case to be used as an example for the prevention of harm to occur. Even though the case was diffirent in the environmental perspective but it does indicate some thought that might helpful for the environmental protection. The case was finally said that Albania responsible for the damge to British warships caused by a failure to warn them of mines in territorial waters. The interpretation of the court indicate the duty to notify as to prevent any harm to occur to the others as stated that "every state's obligation not to allow knowingly its territory to be used for acts contrary to the rights of other states". When the court made the ruling, it does also indicate some liability of the state which fails to notify for any activiy within their jurisdiction that can cause harm to anothers. This case has laid down a basic general prinicple (duty of notification) that has tremendeous impact to many today's treaty.

Therefore, it could be seen that if we look at the nature of the agreement or treaty and understanding the case law, those principle such as precautionary priniciple, duty to notify, principle to assess, principle of not causing harm to the other states, have develop certain obligation to protect the environment, then it could be effectively used to build an obligation to build a case for an international liabiltiy regime for the protection of environment.

Gunther Handl has emphasised the importance of soft law [9] that "Soft Law lays an importance role in the evolution of international environmental law. It devotes international prescriptions that are deems to lack the requisite characteristics of internal legal norms proper but which, notwithstanding this fact, are capable of producing certain effects". Moreover, he stated that "Soft Law" could be a valuable instrument for enhancing or supplementing international law proper.

In fact, frequently "soft law" will capture emerging notions of international public order and thus help extend the realm of legitimate international concern to matters of previously exclusive national jurisdiction. As it could be seen that General prinicple of law and customary law give a lot to tool to protect the environment, and give a general obligation for a liability as well.

\section{Conclusion}

Because both the international custom and the general principles of law have no definite meaning or rule which has no organisation enforcing and striking those rules, however if those two could be used effectively by looking and understanding the nature or how international custom and the general principles of law both have been created and how it have been used, then it would be a very useful and important tool in solving the conflict and be able used to build a case for the environmental protection. The customary and principle of international law could eventually shift the standard of liability that based on fault to stick liability as it would be helpful to protect the environment or at least make the polluter aware of her activity.

However, the weaknesses of current liability system can be seen that because of the lack of case law, therefore, it would be difficult for a court to look for any source or example to formulate the outcome. Regarding to the case in the 
international tribunal, the internatioanl court of Justice has heard onle dispute of note, the nuclear test case and international arbitration has entertained only a few noteable cases, example, the trail Smelter, Lac Lanoux and Great Dam Arbitration. The weaknesses of customary law and general principle of law can also be seen when many state is unwillingly to submit their case to the international tribunal as long as there is not binding treaty and moreover, some state is not willingly to enter to negotiation to entrust any third party. The question of sovereign, equity, liability, and etc always come up in the court room and also many polluter countries do not wish to accept the non-binding principle as a source of law. Moreover, since the independent of many colonial countries after 1950, the question of international customary norms has been arisen. The reliance of the Developed customs law that considered being a developed country's norm is no longer popularly accepted. The new customary law and general principle of law has shifted towards a more soft law or resolution that more developing or underdeveloped has created by their own rather than by the developed country. Therefore, it seems like the customary law and principle of international law has to be redefined.

The international forum should start carefully to look at other source of law, the cutomary law and principle of law incorporate with the stict liability regime seems to be preferable to develop a case to protect the environment. Because the stick liability would be automatically redress the compensation for remedials to the victim states and would be best if those rules are for the preventive measures. However many might argue that what happens if the private party is the one who cause the damage, the answer would lie to that the state has full power to legislate or issue the law that can prevent it to happen. The states has its own duty to take any necessary measures in order to prevent the polution to happen as indicated in the principle of international law. Those rules include the duty to cooperate, notify, consult, to assess the potential transboundary harm, to disclose the dangerous activities, and etc in which it is called the procedural duties [9].

Although stick liability can not be said now as a customery international but there are evidences indicating that, specially in many non-binding treaties/agreements, this norm has emerged as can be seen from the aforementioned case, treaties, and convention. Therefore, it could be seen that the basic liability topic has constantly been shift from fault liability to stick liability from the case law.

Finally, it should be understood that the general principle of law and customary law evidences from many binding-non binding treaties and case law have reflected to the general acceptance as it could be used to build a case in the court room. This has seen as the norms have been emerged and therefore the liability could be compensated from these evidences.

\section{REFERENCES}

[1] "Moratorium mooted on Antarctica mineral use," Times of India, pp. 10, col. 1, May 17, 1984.

[2] K. Kummer, "International management of hazardous wastes, the basel convention and related legal rules with an updated introduction," Oxford Monographs in International Law, 2000, pp. 214-217.

[3] G. Handl, "Transboundary nuclear accidents: the post-Chernobyl multilateral legislative agenda 15,” Ecology L.Q., vol. 203, pp. 222-223, 1988.

[4] A. Amato and K. Engel, International Environmental Law Anthology, Anderson Pub Co, April 1997, p. 11.

[5] M. N. Shaw, International Law, Grotius Publications, 3rd edition, Cambridge, pp. 240, 1991.

[6] K. Kummer, "International management of hazardous wastes, the basel convention and related legal rules with an updated introduction," Oxford Monographs in International Law, January 2000, p. 158.

[7] P. W. Birnie, A. E. Boyle, and C. Redgwell, International Law and the Environment, Oxford University Press, Incorporated, 2009, pp. 91-92.

[8] W. P. Weiner, D. S. Favre, and S. K. Chopra, International Environmental Law, Lupus Publications, 1993, pp. 5-13.

[9] P. Thomas, "Environmental liability: IBA section on business law committee F (international environmental law)," in Proc. the 7th Residential Seminar on Environmental Law, Montreux, Switzerland, International Bar Association series, pp. 193, 1991.

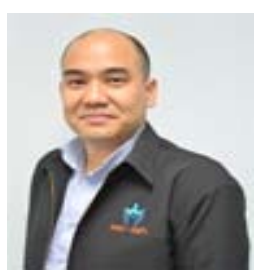

Thepparat Phimolsathien was born in Thailand on February 13, 1976. Dr. Thepparat Phimolsathien received his Ph.D in international trade law from Newcastle Law School, University of Newcastle Upon Tyne, England and his bachelor in economics from University of California, Santa Barbara, USA. He formally worked at the Department of Technical and Economic Cooperation, the Office of the Prime Minister, Thailand and Ministry of Agriculture and Cooperatives, Thailand as a foreign relations officer. Later on he became a lecturer at the Faculty of Social Science and Humanities, Mahidol University and also served as an associate dean for international and public relations. Currently, he is working as a lecturer and secretary of Ph.D. program in industrial management at College of administration and management, King Mongkul's institute of technology (KMITL), Ladkrabang Campus, Thailand. He published several articles and researches including Leaderships in Thai Public Sector 2011, Succession plan in Thai Government Sector 2011. 